\title{
THE EVOCATION OF ENTREPRENEURIAL INTENTIONS: A CONCEPTUAL MODEL of the ENTREPRENEURShip Process
}

\author{
Michael P. Lillis
}

Michael P. Lillis is Professor and Program Director for the Business, Management, \& Leadership Department, Medaille College, 18 Agassiz Circle, Buffalo, NY 14214. Correspondence concerning this paper should be addressed to mlillis@medaille.edu.

\begin{abstract}
The topic of entrepreneurship has gained significant attention in the last few years. Despite a growing body of scholarly work, individual-level process models of entrepreneurship remain incomplete and have not been framed in the context of an all-inclusive model. To address this deficiency, this article introduces a model of entrepreneurship that describes various process conditions under which and mechanisms via which entrepreneurial action is evoked. The objective is to introduce a broad conceptual framework upon which present and future empirical research might be based. By building a deeper understanding of how characteristics of the individual, the situation, and the task impact opportunity recognition and opportunity exploitation, this article suggests
\end{abstract}


several potentially worthwhile avenues for future entrepreneurial research.

Keywords: Entrepreneurship, Entrepreneurial Intentions, Opportunity Recognition, Opportunity Identification, Opportunity Exploitation, Process Model

DOI: https://dx.doi.org/10.15239/j.brcacadjb.2021.11.01.ja04.

\section{INTRODUCTION}

How do we explain the tendency of an individual to recognize, develop and exploit a new business opportunity? Over the last several decades, two streams of entrepreneurial research have emerged from the literature. One stream has focused on characteristics of the entrepreneur, and include individual characteristics such as locus of control (Rauch and Frese, 2007), self-efficacy (Henry et al. 2005), passion (Mitteness et al. 2012), readiness (Schillo and Persaud, 2016) prior experience (Vogel, 2017) and alertness (Hu et al., 2018). A second stream of research has directed attention to contextual issues associated with entrepreneurial activity and include situational variables like technology (Gilbert et al. 2006), social networks (Hormiga et al., 2011), cultural norms (Shane, 1993), management support (Pearce, Kramer and Robbins, 1997), market competition (Zahra, 2005) and the availability of regional level resources (Weiss, Anisimova \& Shirokocca, 2019). Although both streams of research are helpful in identifying both personal characteristics and situational factors that impact entrepreneurial activity, these investigations often adopt an isolated view and need to move beyond a mere description of unconnected individual traits and environmental conditions.

In an attempt to provide a more detailed picture of how psychological, cognitive and behavioral traits can help stimulate new venture activity, behavioral intention models have been used as a framework for understanding how an individual's perceptions impact one's intention to become an entrepreneur. Two dominant behavioral intention models have 
served as a focal point in entrepreneurial research; Shapero and Solol's (1982) entrepreneurial event model (EEM) and Ajzen's (1991) theory of planned behavior (TPB). According to the EEM model, entrepreneurial intention is derived from three factors: the perceived desirability of becoming an entrepreneur, perceived feasibility, and one's propensity to act upon an opportunity (perceptions of control). Alternatively, the TPB model takes into account one's attitude (perceived attractiveness of becoming an entrepreneur), subjective norms (perceived social pressure) and perceived behavioral control (self-efficacy). Given that entrepreneurial intentions are typically seen as one of the most important and unbiased predictors of entrepreneurial behavior (Krueger et al., 2000; Vuorio et al., 2018; Thelken et al., 2020), identifying factors that predict entrepreneurial intention adds tremendous value to our understanding about how new ventures are created.

Drawing from behavioral intention theories, a number of scholars have explored how an individual's perceptions might be intensified so as to strengthen entrepreneurial intentions. For example, Eid et al. (2019) found that the entrepreneurial personal characteristics of autonomy and creativity have a direct effect on an entrepreneur's perceptions of perceived desirability (attraction to the idea of becoming an entrepreneur) and perceived behavioral control (self-evaluation of one's own competence). In another study, Thelken \& Jong (2020) found that selftranscending values (benefits for other individuals, the environment or future generations) positively influenced attitudes (perceived attractiveness) towards sustainable entrepreneurial activities. A third study by Chi \& el. (2020) reported that emotional competence had a significant impact on entrepreneurial self-efficacy (perceived behavioral control). All three studies were able to identify unique individual characteristics that had direct effects on the perceptions of prospective entrepreneurs.. With a focus on both personal characteristics and individual perceptions, these researchers were able to provide a more detailed picture of the process through which entrepreneurial intentions are activated. 
In an effort to move entrepreneurial research beyond a set of personal characteristics, other models recognize the interconnected role of contextual factors in helping to explain how entrepreneurs recognize, develop, and exploit opportunities. This stream of literature draws attention to the relationship between certain situational contingencies and various personal factors in helping to explain why some individuals are better able to recognize, develop and exploit a business opportunity than others. This is consistent with the process-oriented approached of socially situated cognition research, which suggests that entrepreneurs engage their perceptual systems to interact with their environments, which subsequently influences their motivation for taking action (Mitchell et al., 2011). Drawing from this approach, Gonzalez and Winkler (2019) tried to understand how entrepreneurial activity during moments of crises are influenced by the interaction between specific personal factors and environmental stressors. Their model suggests that an entrepreneur's persistence during a moment of crisis is influenced by a self-efficacy threshold, a point where an entrepreneur no longer believes he/she can successfully perform the task required (Gonzlez and Winkler, 2019). According to their findings, this threshold is shaped by three individual-level factors: an entrepreneur's base line for self-efficacy, their prior experience with peak stress levels, and their regenerative capacity for self-efficacy. Their research reveals how individual level differences interact with environmental events, which subsequently influence an individual's entrepreneurial behavior. Undoubtedly, in light of our current economic environment, it is useful to think about how an entrepreneur's self-regulatory capabilities can be strengthened in order to stimulate opportunity recognition and exploitation when environmental threats like Covid-19 prevail.

Although research has increasingly shed more light on how entrepreneurs recognize and exploit opportunities, a holistic and integrated view of the entrepreneurial process is still lacking. By introducing an integrated conceptual model, this investigation hopes to improve understanding of entrepreneurial activity in three respects. First, this paper 
adopts a process-oriented approach to facilitate a better understanding of the antecedents of entrepreneurial activity. It is clear from the above discussion that entrepreneurial frameworks are moving beyond static typologies and are increasingly being conceptualized as a dynamic interaction among characteristics of the prospective entrepreneur and of the situation. However, there are very few process models that explain the process of entrepreneurship (Sakhdari 2016). This paper contributes to the existing literature by directing attention to the examination of the process determinants that potentially enhance or impede new venture activity. A process-oriented focus provides an important frame for the contingent issues and a background for the antecedents of the conceptual model developed.

Second, empirical research on entrepreneurship often provides an incomplete picture of the entrepreneurship process. One obvious reason for this lack of continuity is the absence of a widely accepted theoretical account of entrepreneurial activity. Unfortunately, entrepreneurial studies have not been clearly framed in the context of a consistent and all-inclusive model. Hence, the objective here is to introduce a broad conceptual framework upon which empirical research might be based that includes entrepreneurial phenomenon that arise from interrelated causes. The general aim is to help build a much-needed foundation for understanding, predicting, and controlling the mechanisms via which entrepreneurial action is evoked. These mechanisms represent those initial conditions that constrain and otherwise affect the likelihood of opportunity recognition and the substance and directions of the form of opportunity exploitation and, of course, their outcomes.

Third, the integrative process model developed here not only considers the interactions among individual-level characteristics and situational-level characteristics, but it also considers interactions related to the nature of the task. The tasks of opportunity recognition and opportunity exploitation carry with them certain complexities. As such, the ability to recognize, develop, and exploit opportunities is likely to be influenced 


\section{The BRC Academy Journal of Business Vol. 11, No. 1}

by the nature of the task itself. Given that relatively few entrepreneurial researchers have given consideration to task-level characteristics, the incorporation of task factors in an integrated entrepreneurial model represents a novel approach to the formulation of hypotheses or research propositions that predict entrepreneurial outcomes. To that end, this investigation is expected to contribute theoretically by drawing attention to gaps within the existing entrepreneurship literature associated with the impact of task related variables.

\section{A Proposed Framework}

In an effort to build an all-inclusive definition of entrepreneurship that can be applied to both a business and social purpose context and drawing from a framework proposed by McKenzie et al. (2007), this paper proposes a model that views entrepreneurship as an individual process of identifying opportunities (economic and social) and then engaging in activities that are necessary for exploiting them. Figure 1 reveals a proposed entrepreneurship framework that guides this discussion. The proposed model posits a situation in which an entrepreneur is presented with sensory input about an environment and is interpreting this input for "opportunity" indicators that serve as triggers for entrepreneurial activity

The majority of entrepreneurship studies examine at least one of two primary components: 1) an opportunity recognition process, and 2) an opportunity exploitation process (Kuckertz at al. 2017). Drawing from the literature, both opportunity recognition and opportunity exploitation are seen to be affected by the dynamic interaction among certain process determinants, conditions that affect whether and how inputs are perceived, selected for further processing, and recognized as entrepreneurial opportunities. Three kinds of process determinants are identified in the model: 1) characteristics of the entrepreneur, 2) dimensions of the situation, and 3) particular attributes of the task itself. 
Operationally, the model assumes that the evaluation of sensory input is assessed via comparisons with an evoked set of standards or "reference values". Thus, as Figure 1 depicts, opportunity recognition is an outcome of a comparison process via which entrepreneurs evaluate their input sensory data, relative to some reference value. Discrepancies constitute potential opportunities and motivate behavior oriented toward restoring consonance with the reference value. For an entrepreneur such restoration would include outcomes that range from modest enhancements of an existence reference value, to brand new innovations that lead to a new standard or reference value.

A husband and wife simultaneously getting ready for work in the morning illustrates the process of opportunity identification via reference values. Consider a situation where the husband shaves at the same time his wife takes a hot shower. The steam from the shower causes the bathroom mirror to fog up, thereby causing the husband to have an obstructed view of himself as he attempts to shave. In this situation, incoming sensory information (an obstructed view in the mirror) is compared against a preferred standard (no obstructed view). To an entrepreneur, this discrepancy is a recognized opportunity and motivates a search for solutions that restore consonance with the reference value (an unobstructed view). In this situation, opportunity exploitation might take the form of a heated mirror that does not fog up when someone is in the shower. As this example illustrates, opportunity exploitation from an opportunity recognition process is any (self-regulating) behavior intended to maintain consonance between sensory inputs and a reference value (or standard).

As the model indicates, the opportunity recognition process both influences and is influenced by opportunity exploitation. This is consistent with Ardichvili et al. (2003) who noted that during the exploitation process, an opportunity is subjected to an evaluation process, which may lead to the discovery of additional entrepreneurial opportunities. Likewise, Zahra (2008) and Brockman (2014) both view front-end entrepreneurial 


\section{The BRC Academy Journal of Business Vol. 11, No. 1}

activity as a cyclical, iterative process, emphasizing the role of an evaluation component, thereby allowing the opportunity recognition process to evolve over time. Under this view, the line between opportunity recognition and exploitation might appear blurred, as an entrepreneur strives to make adaptive adjustments by recombining resources that make a venture more viable (Bird 1988). An entrepreneur's strategy thus tends to be a combination of proactive and reactive elements, with certain opportunities being abandoned because they prove to be ineffective. This is also compatible with Sequeira et al.'s (2007) notion of a "gestation period," where a potential entrepreneur engages in a number of pre startup activities that are intended to lead to venture formation.

With regard to the form of exploitation, entrepreneurs can pursue and obtain a range of outcomes from both economic benefit for self (e.g., wealth creation, organizational sustainability, etc.) and social benefits for others (e.g., small scale social problems, massive societal challenges, etc.). The key question relates to the scope and focus of entrepreneurial activity, which is described on a continuum from purely income generating to purely social. Although the destinction between a social and economic venture is not very precise, an entrepreneur's intended mission and actual market impact determine which form of exploitation is realized. Meanwhile the result of exploitation on a relevant environment generates feedback, new sensory information, which occasions another cycle of the continuous stimuli monitoring/assessment process. This paper now turns to those elements of the model that are considered empircally in the literature.

\section{OPPORTUNity RECOGNITION}

A key question in the field of entrepreneurship is what constitutes an opportunity and, more importantly, how are some individuals are better able to identify entrepreneurial opportunities than others. Understanding the process of opportunity recognition is not only useful in understanding how ideas are created but can also serve the very useful purpose of 
helping to develop solutions to important economic and social challenges or problems facing today's society. For an entrepreneur, these kinds of challenges motivate action, which is a behavioral process of looking for ways to minimize or solve a particular problem, such as improving an existing product/service, filling a gap in a less-than-saturated market or constructing a novel market (Read et al., 2009). Therefore, the process of opportunity recognition can essentially be viewed as a process of problem recognition. Further, it is reasonable to expect that research on problem recognition can be used to derive hypotheses about how perceptual, cognitive and personality variables should affect the opportunity recognition capabilities of an entrepreneur.

Research on the problem-recognition and problem-solving processes provides reasonably consistent information about three components that play an influential role in problem recognition/solution performance: conditional features of the task, variations in the context of observation, and attributes of the perceiver. Within the entrepreneurship literature, antecedents to opportunity identification and opportunity exploitation can be observed to operate in a similar manner. Therefore, as seen in Figure 1 , opportunity recognition is seen as an outcome of an entrepreneur's characteristics (perceptual, cognitive and personality), dimensions of the task and particular attributes of the situation.

\section{Entrepreneur Characteristics Impacting Opportunity Recogni-} tion. There has been some success linking an individual's psychological traits and sociodemographic classifications to opportunity recognition. Components such as personality (Ardichvile et al. 2003), intelligence (Shane 2003), social competence (Kreiser, Patel and Fiet, 2013), entrepreneurial alertness (Kirzner, 1997), creativity (Hills et al. 1999), motivation (Herron and Sapienza, 1992), and prior knowledge and experience (Shepherd and DeTienne, 2005, Hajizadeh and Zali, 2016) have all been linked to opportunity recognition.

More recently, the impact of prior knowledge and experience on opportunity recognition has also been linked to organizational inno- 
vations that target social and environmental challenges. For example, Yitshaki and Kropp (2016) found that many prospective social entrepreneurs experience past life events that caused them to develop a greater level of awareness for unmet societal needs, thereby motivating them to recognize and exploit opportunities that have potential for possible social influence. In an exploratory study by Matzembacher et al (2019), prior knowledge of social initiatives heightened sensitivity toward social and environmental problems, which subsequently stimulated new business activity that created social value. Similarly, Tehlken \& de Jong (2020) found that an altruistic motive, driven by a prior knowledge or awareness of the needs of others, had a positive influence on favorable attitudes towards sustainable entrepreneurship; attitudes were found to have a direct effect on an individual's sustainable entrepreneurial intention, identifying an important trigger for stimulating the recognition of entrepreneurial opportunities that have economic, social, and/ or environmental consequences.

Other research has looked at the impact of an entrepreneur's intentions, defined here as an individual's level of commitment towards engaging in entrepreneurial efforts. Research by Valliere (2013) suggests that entrepreneurial intentions are likely to prime value-creating schemata, thereby increasing an entrepreneur's sensitivity to opportunity stimuli. Jarvis (2016) suggests that the strength of one's entrepreneurial intentions and its resulting impact on opportunity recognition is a function of "entrepreneurial identification," the extent to which an individual identifies themselves as an entrepreneur. As discussed earlier, research on entrepreneurial intentions often utilizes Shapero and Solol's (1982) entrepreneurial event model and Ajzen's (1991) theory of planned behavior, theories that highlight the impact of personal characteristics and individual perceptions on entrepreneurial intentions. Given the seminal role that intentions play within the research literature, the link between intentions and entrepreneurial behavior-from opportunity recognition to exploitation-has been well established. (Vuorio et al., 2018). 
Additional research has suggested that the task of opportunity recognition involves unique informational processing characteristics of the entrepreneur. Shaver and Scott (1991) suggest that entrepreneurs are better able to discover opportunities because they have superior information processing ability or scanning techniques than other people. More recently, Renko, et al. (2012) presented a framework whereby entrepreneurs possess unique cognitive processing skills that give them special insights that allow them to perceive inconsistencies between a market need and means to satisfy that market need. Looking beyond a means-ends relationship, Gaglio (2004) suggested that, when it comes to opportunity recognition, entrepreneurs identify unique opportunities, engaging in mental simulations and counterfactual thinking (Kahneman, 1995) as a way to integrate stimuli into patterns that make sense. Similarly, Tang et al. (2012) and Baron (2006) also emphasize pattern recognition as a factor in the opportunity identification process. Accordingly, the task of opportunity recognition involves attending to (or sensing) complex patterns and then using such patterns as the basis for identifying new business opportunities. However, incoming sensory information may not fully reveal all of the indicators of an entrepreneurial opportunity; consequently, prospective entrepreneurs will likely need to "fill in the gaps."

Research by Dew et al. (2009) revealed that "expert" entrepreneurs rely on holistic thinking and frame problems much differently than novices, suggesting that entrepreneurs have a unique ability to perceive different, more comprehensive solutions to the same problem and also have the ability to perceive different problems. Read et al. (2009) found that when marketing a new product or new venture, expert entrepreneurs are more likely to visualize building a whole business, while those who are lower in entrepreneurial expertise are more likely to limit their activities to making isolated marketing decisions. Therefore, it is expected that stylistic differences in how entrepreneur's process information (e.g., differential latencies in encoding and evaluating informational cues) are likely to influence their response to sensory patterns, thereby influencing the extent to which an opportunity would capture the attention of a would-be 
entrepreneur. For new venture creation, these differences in information processing would generate unique entrepreneurial opportunities and unique possible courses of action.

The idea of individual stylistic differences in the tendency to perceive and process information in a global or analytic fashion also relates to measures of field dependence-independence, which are frequently used as indicators of a cognitive style (Goodenough, 1978). Field independent persons engage in analytic thinking and decompose an input into isolated pieces of information and then selectively analyzing each detail. Alternatively, field-dependent persons, treat an input representation as a whole and prefer more global approaches to perceptual processing. In view of individual stylistic differences in the tendency to perceive and process information, and based on the results of the Dew et al. (2009) study, one might expected that field dependent entrepreneurs would have superior opportunity recognition capabilities.

This discussion leads to the following proposition:

Proposition 1: Recognition of entrepreneurial opportunities depends, in part on a variety of individual-level traits and characteristics (psychological, cognitive and/or behavioral). In the case of "cognitive styles", an individual that perceives and processes information in a global fashion (field dependent person) is expected to be better able to distinguish patterns/signals of incipient opportunities from other stimulus distractors, than someone who is field independent. Moreover, given that individuals are more likely to recognize patterns in areas in which they already possess considerable knowledge, an individual's prior knowledge is likely to moderate the relationship between field dependence and opportunity recognition.

\section{Situational Characteristics Impacting Opportunity Recognition.}

In addition to the personality, perceptual skills and cognitive abilities of an entrepreneur, the capacity for opportunity identification also depends on the context in which they are perceived. In other words, "opportunity finding" is a process understood within the context of the social, political, 
and economic environment. Consequently, sociological characteristics (networks, parents, role models, etc.), environmental characteristics (competition, government policy, resources, distractions, etc.), institutional frameworks (organizational structure, market orientation, etc.), and other situational contingencies can greatly impact an individual's sensitivity to opportunity informational cues.

A variety of sociological characteristics have been found to be influential in the opportunity recognition process. For example, empirical research has demonstrated the impact of social networks on entrepreneurial opportunity recognition (Arcdichvili et al. 2003, Batjargal, 2007). Research by Ozgen and Baron (2007) identified three distinct network channels that have a direct, positive impact on opportunity recognition: mentors, informal networks, and professional forums. Other research by Shaw and Carter (2007) determined that networks in which entrepreneurs were "embedded" helped to facilitate unique insights into local conditions thereby helping them to more readily identify opportunities for social entrepreneurship. Consistent with this perspective, Weiss, Anisimova and Shirokova (2019) investigated the role of "social embeddedness," highlighting the importance of regional social capital as a mechanism for identifying and exploiting entrepreneurial opportunities. Similarly, the influence of social capital on opportunity recognition has also been reported by Bhagavatula, et al. (2010), who determined that the greater number of ties an individual possesses, the more likely entrepreneurial opportunities are identified.

Additional research on situational variables have focused on how environmental factors influence both the quantity and quality of recognition opportunities that are available to an entrepreneur. Scholars have shown that as information becomes more readily available, the likelihood of identifying a business opportunity increases (Baron, 2006). Opportunity recognition has been linked to environments that have great velocity, or possess a high degree of discontinuous change (McCarthy et al. 2010). Such environments provide market gaps that would give an entrepreneur 
multiple opportunities to introduce a new product or service. Research by Gielnik et al. (2012) revealed that exposure to multiple markets and industries provides entrepreneurs with a more diverse set of resources, which enhances the positive effect of creativity and divergent thinking, especially as it relates to the idea generation part of the opportunity identification process. Similarly, Jarvis (2016) suggests that "resource munificence," an environment that provides abundant resources, will increase the likelihood that opportunity recognition efforts will be successful.

Institutional frameworks are also influential in the opportunity recognition process. For example, it has been suggested that organizations that adopt a market-oriented framework utilize extensive intelligence gathering activity and are therefore vigorously engaged in opportunity recognition efforts (Slater and Narver, 2000). A market-oriented framework has been found to have a positive relationship to important organizational outcomes such as an innovative climate (Omer and Ahmed, 2016); new product development (Lukas and Ferrell, 2000) and firm performance (Zarah 2008). Other research has looked at the impact of an organization's structural framework, suggesting that highly formalized or bureaucratic organizations can stifle creative solutions because of the lack of material and social support from management. (Hirst, et al. 2011).

From this discussion, the following proposition is derived:

Proposition 2: Situational contexts will have a direct influence on an individual's ability to recognize entrepreneurial opportunities. Current research has identified situation variables that exist at multiple levels (e.g., individual, group, firm, industry). It is reasonable to expect that a contextual variable at one level will moderate the relationship between a contextual variable at another level and individual opportunity recognition. For example, the relationship between a stifling bureaucratic organizational structure (firm level phenomenon) and individual opportunity recognition is likely to be moderated by the quality and quantity of an individual's social capital (individual level phenomenon). 
Task Characteristics Impacting Opportunity Recognition. Much of the work in the area of entrepreneurial opportunity identification remains focused on the importance of individual and situational characteristics. However, a more recent stream of research has directed attention on characteristics of the opportunity itself and its effects on the opportunity recognition process. From this perspective, differences in the relative nature of an opportunity can help to explain some of the observed patterns in entrepreneurial activity (Shane 2003). For example, Smith et al. (2009) investigated how the degree of opportunity tacitness (how well the opportunity is articulated in formal, symbolic language) impacts the opportunity identification process. Their findings suggest that if the object of a search (i.e., the opportunity) is better articulated (codified), the search process is less challenging and is likely to focus on imitated or moderate improvements. In contrast, when an opportunity is more tacit, it is more hidden, and therefore requires a different kind of identification process, one consistent with a "discovery process" whose focus is on major improvements or new innovations (Smith et al. 2009).

Given the potential for different opportunity characteristics, opposing views of opportunity identification are less likely to contradict each other as they each relate to different types of entrepreneurial opportunities. In other words, theories of opportunity recognition can stand independently of each other, largely due to differences in the nature of the opportunities themselves (George et al. 2016). For example, on might argue that some entrepreneurial opportunities are easier to identify than others. Therefore, whether opportunities are "discovered" or "created" could be a function of the level of precision or clarity in which an opportunity presents itself. Certainly, it is reasonable to expect that an individual will be less efficient at identifying entrepreneurial opportunities as they become more abstract or imprecise. Thus, the representational form (concrete vs. abstract) of an entrepreneurial opportunity should produce differences in the ability of an entrepreneur to recognize information cues that signal a potential opportunity and determine which opportunity identification strategy will work, such as discovery or creation. 
Paivio (1986) suggests a models of perceptual and organizational representation around a concreteness-abstractness dimension as it relates to the "form of the represented world." At one extreme (analogue) we have highly concrete, precise, modality-specific representations of objects and events. At the other extreme (propositional), we have completely abstract representations that are only arbitrarily related to real world objects and events. Thus, it is possible to characterize structural representations of stimuli in terms of their presumed degree of correspondence to information about the world. For example, drawings of objects are structurally more abstract than photographs because they have fewer details. The basic implication for entrepreneurial opportunity recognition is that an individual will be less efficient at identifying potential entrepreneurial opportunity patterns as they become more abstract in their relationship to the real world.

This leads to the following proposition:

Proposition 3: Task-level characteristics will have a direct influence on opportunity recognition. For example, incoming sensory information displayed in propositional form is less likely to be identified as an entrepreneurial opportunity than that which is displayed in analogue form.

\section{OPPORTUNITY EXPLOITATION}

Once an opportunity is identified, an entrepreneur must shift their focus from assessing the viability of an opportunity to determining how to exploit it. Opportunity exploitation has been associated with a variety of activities, including venture planning, concept and product testing, financing, production, and market testing (Block and MacMillan, 1985). Given the multitude of endeavors that are essential for taking a new opportunity and bringing it to market, it is not surprising that entrepreneurs are typically viewed as individuals who have considerable drive, energy, ambition and autonomy (Carland et al. 1984). To capture the essence of the exploitation process, entrepreneurship has been described 
in the literature as organization initiation (Aldrich and Martinez, 2001), market pioneering (Covin et al. 2000), creation of new ventures (Dew et al. 2009), and the formation of new means, ends, or means-ends relationships (Eckhardt and Shane, 2003). From these and other descriptions in the literature, it is clear that opportunity exploitation is a necessary and essential component of entrepreneurship.

\section{Entrepreneur Characteristics Impacting Opportunity Exploitation.}

These capabilities relate to the human capital (Otani, 1996) that is essential for an opportunity to become exploited. For example, formal education as a source of human capital was found to have a significant positive effect on the exploitation of innovation opportunities (Bayon et al. 2016). Increased exploitation skills have also been found to be associated with motivation (Reynolds et al. 1999), knowledge resources (Alvarez and Busenitz, 2001), persuasion skills (Rogers, 1995), and education (Long and McMullan, 1984). Moreno (2008) has shown the willingness to exploit opportunities depends on such things as prior experience in activities related to the present business activity and an entrepreneur's level of education. The likelihood of exploitation has also been linked with risktaking propensity (Caliendo et al. 2009), self-confidence (Bayon et al. 2016), learning styles (Corbett, 2005), self-efficacy (Krueger and Carsrud, 1993), and entrepreneurial identification (Jarvis, 2016).

Other researchers have demonstrated a strong positive relationship between entrepreneurial intentions and opportunity exploitation (e.g., Dimov, 2007; Boyd and Vozikis, 1994; Vissa, 2011). For example, Sequeira et al. (2007) considers intentions to be a vital component of a "gustation period," during which an entrepreneur engages in certain "nascent behaviors", pre start-up tasks that will eventually lead to new venture creation. Findings from their study suggest that entrepreneurial intentions motivate entrepreneurs to engage in a number of preparation activities (business planning, financing, and other set up activities) that lead to opportunity exploitation. Jarvis (2016) also acknowledges the impact of entrepreneur's intention, but suggests it is moderated by the 
entrepreneur's domain relevant knowledge, or how much knowledge a person has about a given domain or industry. Other determinants of entrepreneurial intentions are suggested by Ojiaku et al. (2018) who found environmental factors, perceived desirability, risk tolerance and self-efficacy to have a strong influence on entrepreneurial intentions. The subsequent impact of these heightened entrepreneurial intentions on opportunity exploitation would likely follow.

This discussion leads to the following proposition:

Proposition 4: Opportunity exploitation is contingent upon a variety of individual-level traits and characteristics (psychological, cognitive and/or behavioral). Drawing from prior research, it is reasonable to expect that prospective entrepreneurs are more likely to engage in pre-exploitation activities in areas in which they already possess domain relevant knowledge. Consequently individual knowledge and prior experience are likely to moderate the relationship between entrepreneurial intentions and opportunity exploitation.

\section{Situational Characteristics Impacting Opportunity Exploitation.}

Researchers have considered the impact of a variety of situational characteristics on opportunity exploitation. Some scholars have looked at whether there are resources available in adequate abundance that can support entrepreneurial initiatives. For example, Castrogiovanni (2002) speculated whether the environment provides enough resources, such as venture capital and human resources, to support both established organizations and new entrants. Others have suggested that a willingness to exploit entrepreneurial opportunities depends on such things as opportunity cost (Amit et al. 1995), social ties to investors (Aldrich \& Zimmer, 1986), and social networks (Sequeira et al. 2007). In an investigation of the intention-opportunity exploitation link, Weiss et al (2019) looked at the moderating effect of contextual factors in the form of regional social capital. Their findings revealed that exploitation likelihoods are enhanced by regional level conditions, operationalized as: 1) the level of shared 
hierarchical values (child obedience), 2) cultural diversity, and 3) the level of interpersonal trust that is perceived within a geographic region.

Within the corporate entrepreneurship literature, individual level activity in a corporate environment is subjected to a variety of firm-level situational contingencies. For example, prior studies have shown the impact of an organization's strategic orientation (Kakapour et al. 2016), barriers to technological adoption (Laplume et al. 2014), organizational design (Foss et al. 2014), and organizational structure (Bhardwaj and Momaya, 2006) on the entrepreneurial efforts of individuals within an organization. Other organization-based situational contingencies have been identified, including: the diversity of the top management team (Hayton 2005), quality of business and institutional ties (Yiu et al. 2007), information system capabilities of a firm (Simek, et al. 2009), structural factors (Burgers \& Covin, 2016), absorptive capacity (Zahra, 2015), and networking capabilities of a firm (Sakhdari et al. 2014).

In a recent review of the literature, Kamal Sakhdari (2016) identified four categories of situational antecedents that are likely to influence entrepreneurial behavior by an organizations employees: 1) Top management team issues (size, diversity, etc.), 2) A firm's capabilities (reputational capital, technological competencies, institutional ties, coordination of resources, etc.), 3) Network/dyad level phenomenon (inter-firm relationships, external knowledge access, knowledge sharing mechanisms, etc...), and 4) environmental variables (environmental dynamism, complexity, privatization, etc...). These studies reveal important insights about the influence of organizational level antecedents to opportunity exploitation at the individual level. Clearly, an area of further study within the realm of corporate entrepreneurship would be to better understand how these factors stimulate the entrepreneurial activity of individual employees within a firm (Sakhdari and Bidakhavidi, 2016)

From this discussion, the following proposition is derived:

Proposition 5: Situational contexts will have an influence on an individual's likelihood to exploit entrepreneurial opportunities. For example, the avail- 
ability of venture capital will moderate the relationship between entrepreneurial intentions and opportunity exploitation.

Task Characteristics Impacting Opportunity Exploitation. A decision to exploit an opportunity can be influenced by characteristics of the opportunity as well. In their development of a framework of the entrepreneurial process, Plummer et al. (2007) identify an "entrepreneurial strategizing" phase of the exploitation process in which an entrepreneur seeks to match a given opportunity with the best strategy for maximizing that opportunity. According to the framework, the choice of strategy is influence by both characteristics of the opportunity and the nature of the environment. The degree of "strategy-opportunity-environment fit" determines the potential for realizing returns for the entrepreneur's efforts. Within this framework, differences in entrepreneurial opportunities play a significant role in the exploitation process, as characteristics of the opportunity influence which mode of exploitation is chosen. Although research in this area is considerably underdeveloped, the question as to whether an opportunity is exploitable has also been suggested to be a function of other opportunity characteristics such as opportunity quality (Wang et al. 2013) and the expected value of an opportunity (Shane and Venkataraman, 2000).

The tasks required for opportunity exploitation can also be understood in the context of the type of entrepreneurial venture. In a recent investigation of venture typologies, Morris et al. (2016) identified four venture types: 1) Survival ventures are launched due to a lack of employment opportunities and acquire customers through friends, family and doorto-door sales, 2) Lifestyle ventures seek to be part of the local business community and have a stable income stream, making modest reinvestments to stay competitive (bars, restaurants, galleries, etc.), 3) Managed growth ventures have a workable business model that seek stable growth over time (by occasionally introducing new products, entering new markets, expanded facilities, or developing a strong regional brand), and 4) Aggressive/High growth ventures seek exponential growth and 
are funded by equity capital and focus on building market share with a national or international market. This typology proposes different configurations of organizational structure, ranging from less formalizes/less comprehensive structures (survival ventures) to more formalized/ more comprehensive structures (aggressive/high growth ventures). Based on the diverse operational characteristics and resource needs of each type of venture, it is expected that the task of opportunity exploitation will be different for each venture type. Specifically, as venture types become increasingly formalized/comprehensive, it is expected that more advanced exploitation skills and greater venture capital resources would be required. Clearly, additional research is needed to more fully understand the importance of relative differences between the different task requirements of each venture type and how these differences influence the exploitation process.

This leads to the following proposition:

Proposition 6: Task-level characteristics will have an influence on an individual's ability to exploit entrepreneurial opportunities. For example, entrepreneurial opportunities that target less comprehensive venture types (survival ventures) are more likely to be exploited than opportunities that target more comprehensive venture types (aggressive/high growth ventures).

\section{Conclusion}

From a theoretical standpoint, the development of a broad conceptual framework can help to identify specific variables that contribute to entrepreneurial performance and may provide insights into the complex process foundations of entrepreneurship. More specifically, by maintaining a process focus, researchers may achieve a more complete understanding of the psychophysical aspects and mental cognitions that underlie the foundation of opportunity recognition and opportunity exploitation. This emphasis should encourage researchers to look closely 
at current developments in cognitive psychology in order to advance theory and methodology in entrepreneurial research.

Research to advance the conceptual model developed here might take several directions. First, the study of antecedents could be extended to include a number of other inherent perceiver characteristics, situational characteristics and task characteristics. This is especially true for task characteristics, as the links between the nature of the opportunity and entrepreneurial related activities (opportunity identification and opportunity exploitation) are not well explored. Second, other measures of performance that relate to the efficiency of opportunity recognition and opportunity exploitation could provide a more valid index of competence in the evocation and exploitation of opportunities. The lack of distinct measures for each of these constructs impedes efforts to identify distinguishing antecedents of entrepreneurship (Kuckertz et al. 2017). Finally, applications of the conceptual model to opportunity cues based on real world entrepreneurial ventures could help to extend the generalizability of the proposed model. 


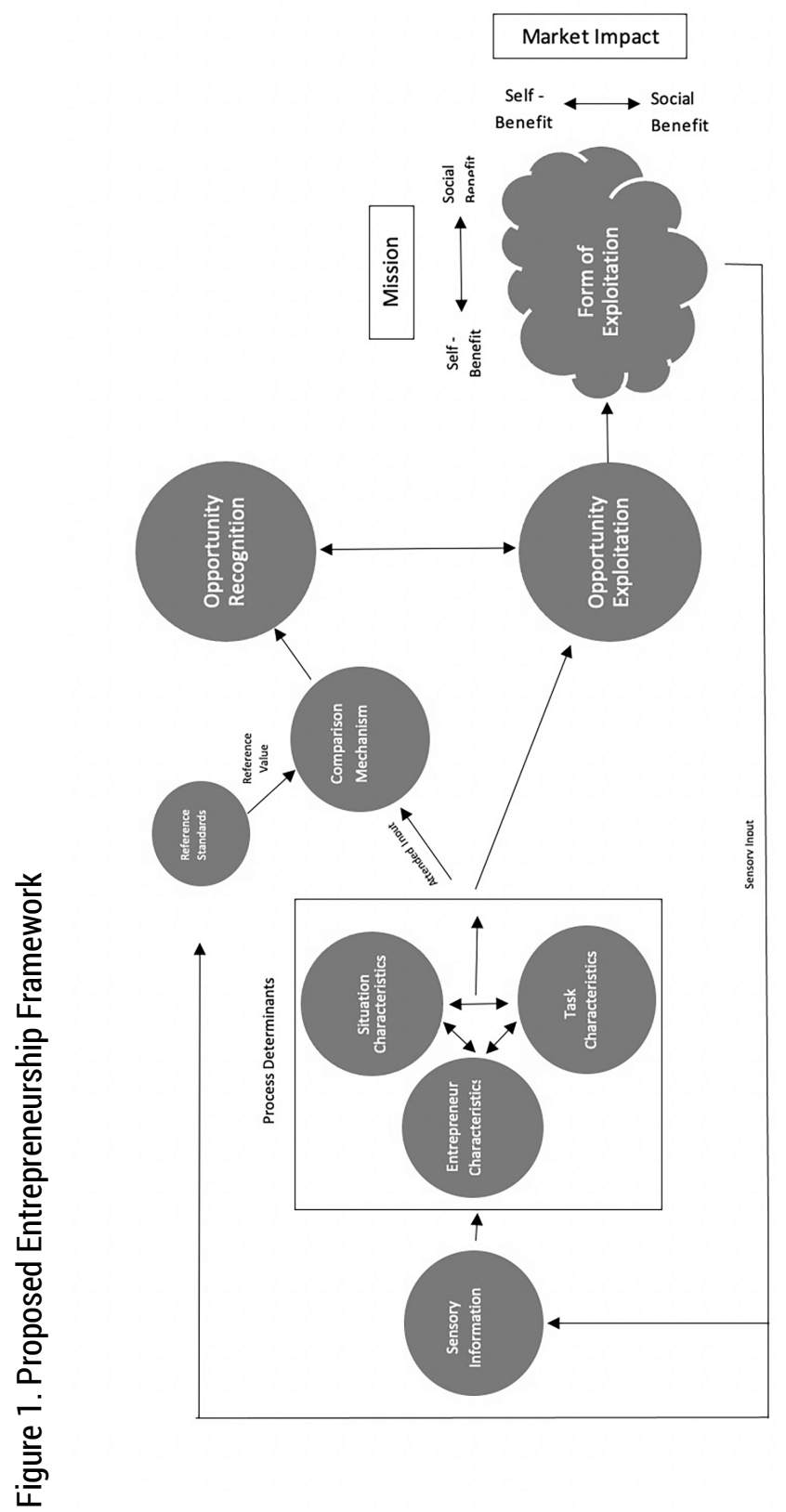




\section{REFERENCES}

Ajzen, I. (1991). The theory of planned behavior. Organizational behavior and human decision processes, 50(2), 179-211.

Aldrich, H, \& Zimmer, C. (1986). Entrepreneurship through social networks. In S.D. R. Smilor (Ed), The art and science of entrepreneurship. Cambridge, MA: Ballinger.

Aldrich, H. E., \& Martinez, M. A. (2001). Many are called, but few are chosen: An evolutionary perspective for the study of entrepreneurship: ET\&P. Entrepreneurship Theory and Practice, 25(4), 41-56.

Alvarez, S. A., \& Busenitz, L. W. (2001). The entrepreneurship of resource-based theory. Journal of Management, 27(6), 755-775.

Amit, R., Muller, E., \& Cockburn, I. (1995). Opportunity costs and entrepreneurial activity. Journal of Business Venturing, 10(2), 95.

Ardichvili, A., Cardozo, R., \& Ray, S. (2003). A theory of entrepreneurial opportunity identification and development. Fournal of Business Venturing, 18(1), 105-123.

Baron, R. A. (2006). Opportunity recognition as pattern recognition: How entreprenuers "connect the dots" to identify new business opportunities. The Academy of Management Perspectives, 20(1), 104-119.

Batjargal, B. (2007). Network triads: Transitivity, referral and venture capital decisions in china and russia. Journal of International Business Studies, 38(6), 998-1012.

Bayon, M. C., Lafuente, E., \& Vaillant, Y. (2016). Human capital and the decision to exploit innovative opportunity. Management Decision, 54(7), 1615-1632.

Bhagavatula, S., Elfring, T., van Tilburg, A., \& van de Bunt, G. G. (2010). How social and human capital influence opportunity recognition and resource mobilization in india's handloom industry. Fournal of Business Venturing, 25(3), 245.

Bhardwaj, B. R., \& Momaya, K. (2006). Role of organizational flexibility for corporate entrepreneurship: Case study of FedEx corporation. Global fournal of Flexible Systems Management, 7(1), 37-44. 
Bird, B. J. (1988). Implementing entrepreneurial ideas: The case for intention. Academy of Management. The Academy of Management Review, 13(3), 442.

Block, Z., \& MacMillan, I. C. (1985, Sep). Milestones for successful venture planning. Harvard Business Review, 63, 184.

Boyd, N. G., \& Vozikis, G. S. (1994). The influence of self-efficacy on the development of entrepr: ET\&P. Entrepreneurship Theory and Practice, 18(4), 63.

Brockman, B. K. (2014). ENTREPRENEURIAL ALERTNESS IN OPPORTUNITY IDENTIFICATION AND OPPORTUNITY DEVELOPMENT. Journal of Business and Entrepreneurship, 26(2), 27-44.

Burgers, J. H., \& Covin, J. G. (2016). The contingent effects of differentiation and integration on corporate entrepreneurship. Strategic Management fournal, 37(3), 521-540.

Caliendo, M., Fossen, F. M., \& Kritikos, A. S. (2009). Risk attitudes of nascent entrepreneurs-new evidence from an experimentally validated survey. Small Business Economics, 32(2), 153-167.

Carland, J. W., Hoy, F., Boulton, W. R., \& Carland, J. A. C. (1984). Differentiating entrepreneurs from small business owners: A conceptualization. Academy of Management.the Academy of Management Review, 9(2), 354.

Castrogiovanni, G. J. (2002). Organization task environments: Have they changed fundamentally over time? fournal of Management, 28(2), 129-150.

Chien-Chi, C, Sun, B., Yang, H., Zheng, M., \& Li B. (2020). Emotional competence, entrepreneurial self-efficacy, and entrepreneurial intention: A study based on china college students' social entrepreneurship project. Frontiers in Psychology 11, 547627. https:// doi.org/10.3389/fpsyg.2020.547627

Corbett, A. C. (2005). Experiential learning within the process of opportunity identification and exploitation: ET\&P. Entrepreneurship Theory and Practice, 29(4), 473-491. 
Covin, J. G., Slevin, D. P., \& Heeley, M. B. (2000). Pioneers and followers: Competitive tactics, environment, and firm growth. Fournal of Business Venturing, 15(2), 175-210.

Dew, N., Read, S., Sarasvathy, S. D., \& Wiltbank, R. (2009). Effectual versus predictive logics in entrepreneurial decision-making: Differences between experts and novices. fournal of Business Venturing, 24(4), 287.

Dimov, D. (2007). From opportunity insight to opportunity intention: The importance of person-situation learning match: ET\&P. Entrepreneurship Theory and Practice, 31(4), 561-583.

Eckhardt, J. T., \& Shane, S. A. (2003). Opportunities and entrepreneurship. Fournal of Management, 29(3), 333-349.

Eid, R., Badewi, A., Selim, H., \& El-Gohary, H. (2019). Integrating and extending competing intention models to understand the entrepreneurial intention of senior university students. Education + Training, 60(2), 234-254.

Foss, N. J., Lyngsie, J., \& Zahra, S. A. (2013). The role of external knowledge sources and organizational design in the process of opportunity exploitation. Strategic Management fournal, 34(12), 1453-1471.

Gaglio, C. M. (2004). The role of mental simulations and counterfactual thinking in the opportunity identification process: ET\&P. Entrepreneurship Theory and Practice, 28(6), 533-552.

George, N.M., Parida, V., Lahti, T., \& Wincent, J. (2016). A systematic literature review of entrepreneurial opportunity recognition: Insights on influencing factors. International Entrepreneurship and Management fournal, 12(2), 309-350.

Gielnik, M. M., Frese, M., Graf, J. M., \& Kampschulte, A. (2012). Creativity in the opportunity identification process and the moderating effect of diversity of information. Journal of Business Venturing, 27(5), 559.

Gilbert, B.A., McDougall, P.P. \& Audretsch, D.B. (2006), New venture growth: A review and extension, fournal of Management, 32(6), 926-950. 
Gonzalez, K., \& Winkler, C. (2019). The entrepreneurial breaking point: undergoing moments of crisis. Management Decision, 57(11), 2853-2868.

Goodenough, D.R. (1978). Field dependence. In H. London \& J. Exner, Jr (Eds), Dimensions of personality. New York: Wiley.

Hajizadeh, A., \& Zali, M. (2016). Prior knowledge, cognitive characteristics and opportunity recognition. International fournal of Entrepreneurial Behaviour \& Research, 22(1), 63-83.

Hayton, J. C. (2005). Competing in the new economy: The effect of intellectual capital on corporate entrepreneurship in high-technology new ventures. $R \& D$ Management, 35(2), 137-155.

Henry, C., Hill, F., \& Leitch, C. (2005). Entrepreneurship education and training: Can entrepreneurship be taught? part I. Education \& Training, 47(2), 98-111.

Herron, L., \& Sapienza, H. J. (1992). The entrepreneur and the initiation of new venture launch activities: ET\&P. Entrepreneurship Theory and Practice, 17(1), 49.

Hills, G.E., Srader, R.C., \& Lumpkin, G.T. (1999). Opportunity Recognition as a Creative Process. Frontiers of Entrepreneurship Research, 216-227.

Hirst, G., Van Knippenberg, D., Chen, C., \& Sacramento, C. A. (2011). HOW DOES BUREAUCRACY IMPACT INDIVIDUAL CREATIVITY? A CROSS-LEVEL INVESTIGATION OF TEAM CONTEXTUAL INFLUENCES ON GOAL ORIENTATION-CREATIVITY RELATIONSHIPS. Academy of Management fournal, 54(3), 624.

Hormiga, E., Batista-Canino, R.M. \& Sanchez-Medina, A. (2011). The impact of relational capital on the success of new business start-ups. Journal of Small Business Management, 49(4), 617-638.

Hu, R., Wang, L., Zhang, W., \& Bin, P. (2018). Creativity, proactive personality, and entrepreneurial intention: The role of entrepreneurial alertness. Frontiers in Psychology, 9, 951. https://doi.org/10.3389/fpsyg. 2018.00951 
Jarvis, L. C. (2016). Identification, intentions and entrepreneurial opportunities: An integrative process model. International fournal of Entrepreneurial Behaviour \& Research, 22(2), 182-198.

Kahneman, D. (1995). Varieties of counterfactual thinking, in Roese, NJ and Olson, J.M. (Eds), What Might Have Been: The Social Psychology of Counterfactual Thinking, Erlbaum Associates, Mahwah, NJ, 375-395.

Kakapour, S., Morgan, T., Parsinejad, S., \& Wieland, A. (2016). Antecedents of corporate entrepreneurship in iran: The role of strategic orientation and opportunity recognition. Journal of Small Business and Entrepreneurship, 28(3), 251-266.

Kirzner, I. M. (1997). Entrepreneurial discovery and the competitive market process: An austrian approach. Journal of Economic Literature, 35(1), 60-85.

Kreiser, P.M., Pankaj, P.C., \& James, F.O. (2013). The influence of changes in social capital on firm-founding activities. Entrepreneurship Theory and Practice, 37(3), 539-567.

Krueger, N.G. \& Carsrud, A.L. (1993). Entrepreneurial intentions: applying the theory of planned behavior. Entrepreneurship \& Regional Development, 5 (4), 315-330.

Kuckertz, A., Kollmann, T., Krell, P., \& Stöckmann, C. (2017). Understanding, differentiating, and measuring opportunity recognition and opportunity exploitation. International fournal of Entrepreneurial Behaviour \& Research, 23(1), 78-97.

Laplume, A.O., Pathak, S., Xavier-Oliveira, E., (2014) The politics of intellectual property rights regimes: An empirical study of new technology use in entrepreneurship. Technovation 34(12), 807-816.

Long, W. \& McMullan, W.E. (1984). Mapping the new venture opportunity identification process, Frontiers of Entrepreneurship Research, Babson College, Wellesley, MA, 567-590.

Lukas, B. A., \& Ferrell, O. C. (2000). The effect of market orientation on product innovation. Fournal of the Academy of Marketing Science, 28(2), 239-247. 
Matzembacher, D.E., Raudsaar, M., de Barcellow, M.D., \& Mets, T., (2019). Sustainable entrepreneurial process: From Idea Generation to Impact Measurement. Sustainability, 11(21), 5892 doi:10.3390/su11215892.

McCarthy, I. P., Lawrence, T. B., Wixted, B., \& Gordon, B. R. (2010). A multidimensional conceptualization of environmental velocity. Academy of Management.the Academy of Management Review, 35(4), 604-626.

McKenzie, B., Ugbah, S. D., \& Smothers, N. (2007). "WHO IS AN ENTREPRENEUR?" IS IT STILL THE WRONG QUESTION? Academy of Entrepreneurship fournal, 13(1), 23-43.

Mitchell, R.K., Randolph-Seng, B., \& Mitchell, J.R., (2011). Socially situated cognition: Imagining new opportunities for entrepreneurship research. Academy of Management Review, 36(4), 774-776.

Mitteness, C., Sudek, R., \& Cardon, M. S. (2012). Angel investor characteristics that determine whether perceived passion leads to higher evaluations of funding potential. fournal of Business Venturing, 27(5), 592.

Moreno, J. d. J. (2008). AN EMPIRICAL ANALYSIS OF ENTREPRENEURIAL OPPORTUNITY IDENTIFICATION AND THEIR DECISIVE FACTORS: THE CASE OF NEW SPANISH FIRMS. International fournal of Entrepreneurship, 12, 11-37.

Morris, M.H., Neurmeryer, X., Jan, Y., Kuratko, D.F. (2016). Distinguishing types of entrepreneurial ventures: An identity-based perspective. Journal of Small Business Management, 56(3), 453-474.

Ojiaku, O. C., Nkamnebe, A. D., \& Nwaizugbo, I. C. (2018). Determinants of entrepreneurial intentions among young graduates: Perspectives of push-pull-mooring model. fournal of Global Entrepreneurship Research, 8(1), 1-17.

Omer, N., \& Ahmed, A. (2016). Relationship between innovation climate, market orientation and corporate entrepreneurship. International Review of Management and Marketing, 6(3)

Otani, K. (1996). A human capital approach to entrepreneurial capacity. Economica, 63(250), 273. 
Ozgen, E., \& Baron, R. A. (2007). Social sources of information in opportunity recognition: Effects of mentors, industry networks, and professional forums*. Fournal of Business Venturing, 22(2), 174.

Paivio, A. (1986). Mental representations: A dual coding approach. New York: Oxford University Press.

Pearce, J.A., Kramer, T.R., \& Robbins, D.K. (1997). Effects of managers' entrepreneurial behavior on subordinates. fournal of Business Venturing, 12(2), 147-160.

Plummer, L. A., Haynie, J. M., \& Godesiabois, J. (2007). An essay on the origins of entrepreneurial opportunity. Small Business Economics, 28(4), 363.

Rauch, A., \& Frese, M. (2007). Let's put the person back into entrepreneurship research: A meta-analysis on the relationship between business owners' personality traits, business creation, and success. European fournal of Work and Organizational Psychology, 16(4), 353.

Read, S., Dew, N. Sarasvathy, S., Song, M., \& Wiltbank, R. (2009). Marketing under uncertainty: The logic of an effectual approach. fournal of Marketing, 73(3), 1-18,

Renko, M., Shrader, R. C., \& Simon, M. (2012). Perception of entrepreneurial opportunity: A general framework. Management Decision, 50(7), 1233-1251.

Reynolds, P. D., Hay, M. \& Camp S.M., (1999). GEM Global 1999 Executive Report, Kansas City: Kaufman Center.

Rogers, E.M. (1995). Diffusion of innovations (Fourth Edition). New York, NY: The Free Press.

Sakhdari, K. (2016). Corporate entrepreneurship: A review and future research agenda. Technology Innovation Management Review, 6(8), 5-18.

Sakhdari, K., \& Bidakhavidi, E. J. (2016). Underground innovation: How to encourage bootlegging employees to disclose their good ideas. Technology Innovation Management Review, 6(3), 5-12.

Sakhdari, K., Burgers, H., \& Davidsson, P. (2014). Unpacking the networking capabilities and corporate entrepreneurship relationship. In Academy of Management Proceedings (1):13260 
Schillo, R. S., Persaud, A., \& Jin, M. (2016). Entrepreneurial readiness in the context of national systems of entrepreneurship. Small Business Economics, 46(4), 619-637.

Sequeira, J., Mueller, S. L., \& McGee, J. E. (2007). THE INFLUENCE OF SOCIAL TIES AND SELF-EFFICACY IN FORMING ENTREPRENEURIAL INTENTIONS AND MOTIVATING NASCENT BEHAVIOR. Fournal of Developmental Entrepreneurship, 12(3)

Shane, S. (1993). Cultural influences on national rates of innovation. fournal of Business Venturing, 8(1), 59-73.

Shane, S. (2003). A General Theory of Entrepreneurship, Edward Elgar Publishing. Northhampton, MA.

Shane, S., \& Venkataraman, S. (2000). The promise of entrepreneurship as a field of research. Academy of Management.the Academy of Management Review, 25(1), 217-226.

Shapero, A., \& Sokol, L. (1982). Social dimensions of entrepreneurship, in Kent, C.A., Sexton, D.L. \& Vesper, K.H. (Ed), The Encyclopedia of Entrepreneurship, Prentice-Hall, Englewood Cliffs, NJ, 72-90.

Shaver, K. G., \& Scott, L. R. (1991). Person, process, choice: The psychology of new venture creation: ET\&P. Entrepreneurship Theory and Practice, 16(2), 23.

Shaw, E., \& Carter, S. (2007). Social entrepreneurship: Theoretical antecedents and empirical analysis of entrepreneurial processes and outcomes. Fournal of Small Business and Enterprise Development, 14(3), 418-434.

Shepherd, D. A., \& DeTienne, D. R. (2005). Prior knowledge, potential financial reward, and opportunity identification: ET\&P. Entrepreneurship Theory and Practice, 29(1), 91-112.

Simsek, Z., Lubatkin, M. H., Veiga, J. F., \& Dino, R. N. (2009). The role of an entrepreneurially alert information system in promoting corporate entrepreneurship. Fournal of Business Research, 62(8), 810.

Slater, S. F., \& Narver, J. C. (2000). Intelligence generation and superior customer value. Fournal of the Academy of Marketing Science, 28(1), 120-127. 
Smith, B. R., Matthews, C. H., \& Schenkel, M. T. (2009). Differences in entrepreneurial opportunities: The role of tacitness and codification in opportunity identification*. Journal of Small Business Management, 47(1), 38-57.

Tang, J., Kacmar, K. M., \& Busenitz, L. (2012). Entrepreneurial alertness in the pursuit of new opportunities. fournal of Business Venturing, 27(1), 77.

Thelken, H.N., \& de Jong, G. (2020). The impact of values and future orientation on intention formation within sustainable entrepreneurship. Fournal of Cleaner Production, 266, https://doi.org/ 10.1016/j.jclepro.2020.122052

Valliere, D. (2013). Towards a schematic theory of entrepreneurial alertness. fournal of Business Venturing, 28(3), 430.

Vissa, B. (2011). A MATCHING THEORY OF ENTREPRENEURS' TIE FORMATION INTENTIONS AND INITIATION OF ECONOMIC EXCHANGE. Academy of Management fournal, 54(1), 137.

Vogel, P. (2017). From venture idea to venture opportunity. Entrepreneurship Theory and Practice, 41, 943-971.

Vuorio, A.M., Puumalainen, K., \& Fellnhofer, K. (2018). Drivers of entrepreneurial intentions in sustainable entrepreneurship. International fournal of Entrepreneurial Behavior \& Research, 24 (2), 359-381.

Yitshaki, R., \& Kropp, F. (2016). Entrepreneurial passions and identities in different contexts: A comparison between high-tech and social entrepreneurs. Entrepreneurship \& Regional Development, 28, 206-233.

Yiu, D. W., Lau, C., \& Bruton, G. D. (2007). International venturing by emerging economy firms: The effects of firm capabilities, home country networks, and corporate entrepreneurship. fournal of International Business Studies, 38(4), 519-540.

Wang, Y., Ellinger, A. D., \& WU Y. J. (2013). Entrepreneurial opportunity recognition: An empirical study of R\&D personnel. Management Decision, 51(2), 248-266.

Weiss, J., Anisimova, T. \& Shirokova, G. (2019). The translation of entrepreneurial intention into start-up behavior: The moderating role of 
regional social capital. International Small Business fournal: Researching Entrepreneurship, 37(5), 473-501.

Zahra, S.A. (2005). A theory of international new ventures: A decade of research. Fournal of International Business Studies, 36(1), 20-28.

Zahra, S. A. (2008). The virtuous cycle of discovery and creation of entrepreneurial opportunities. Strategic Entrepreneurship fournal, 2(3), 243.

Zahra, S. A. (2015). Corporate entrepreneurship as knowledge creation and conversion: The role of entrepreneurial hubs. Small Business Economics, 44(4), 727-735. doi:http:// dx.doi.org.ezproxy.medaille.edu/10.1007/s11187-015-9650-4

\section{Citation Information}

Lillis, Michael P. "The Evocation of Entrepreneurial Intentions: A Conceptual Model of the Entrepreneurship Process." The BRC Academy Journal of Business 11, no. 1 (2021): 87-119. https://dx.doi.org/10.15239/ j.brcacadjb.2021.11.01.ja04 